\title{
The Analysis of imposition, deposit and reporting of value-added tax by PT. Seimitsu Diagnostics
}

\author{
Ary Lestari, Yusrizal, Lukman Hakim N, Danang Djoko Susilo, Hasan Rachmany \\ Taxation Department, Sekolah Tinggi Perpajakan Indonesia \\ Email: arylestari05@gmail.com
}

\begin{abstract}
The Taxation Law in Indonesia refers to Self-Assessment System, which is giving trust to the taxpayer to calculate, deposit and report by themselves about the amount of tax owed according to the regulation of taxation law. While the purpose of writing this thesis generally is to know about the imposition, deposit and reporting of value-added tax by PT. Seimitsu Diagnostics has appropriated with the provision of value added tax law within the applicable taxation enforcement rules and to know how PT. Seimitsu Diagnostics to overcome the obstacle encountered in implementing the value-added tax collection and to know the effort that have been taken to overcome the problems. The writer does this research by collecting data and processing method and analysing data. The writer does the research in the company to get the data and collecting them. The obstacle is about the output tax difference always bigger than the input tax, so it can cause there are the amount of underpaid taxes and the company is considered to be negligence in the deposit and report the underpaid taxes on every tax period or tax year so according to article 8 section (2) Law number 6 Year 1983 about the General Condition and tax procedure of the company got penalty to a $2 \%$ interest in a month for the underpayment amount.
\end{abstract}

Keywords: Analysis of imposition; deposit; reporting; Value-added tax

\section{INTRODUCTION}

In attempting to increase the state revenue through tax sector and to encourage the growth rate of Indonesian economic, the government has issued several policies in tax field. One of the policy is the enactment of the tax collection system by self-assessment, it means that the taxpayer is given trust to count themselves the amount of tax owed, calculating the tax that has been paid by themselves or withheld from other party, paying the tax deficiency, and reporting the implementation of tax obligation to the tax authorities. By implementing a selfassessment system, so every taxpayer needs adequate knowledge about tax calculation, especially in value-added tax (Hanifah \& Yudianto, 2019; Okello, 2014; Park, 2019; Wadesango et al., 2018).

Basically, Value-Added Tax is tax on consumption of goods and services in Indonesian State Customs Area including delivery of taxable goods (BKP) and taxable services (JKP). However according to social, economic and culture consideration there are several deliveries of certain goods and services which is not subject to value-added tax. In the legal order of Republic Indonesia Number 8 Year 1983 as has been changed with Law number 11 Year 1994 


\section{8| Jurnal Office: Jurnal Pemikiran Ilmiah dan Pendidikan Administrasi Perkantoran \\ Vol. 6, No. 1, January-June 2020, Page 37-44}

and Law number 18 Year 2000, the last is the third change with the Law number 42 Year 2009 about Value-Added Tax of Goods and Services, and Luxury Sales Tax (next in this final project of writing called UU PPN) goods and services that are not taxes regulated in article 4A section (2) and section (3).

To count value-added tax owed (Aminu, 2019; Benzarti et al., 2017; Harjanti et al., 2019). Taxable Enterprise (PKP) must count the difference between the output tax and the input tax, which is simply formulated the amount of value added tax (PPN) equal with the Output Tax minus the Input Tax. If the Output Tax is less than the Input Tax, so the difference is the compensated tax excess to the next Tax Period. While, if the Output Tax is bigger than the Input Tax, then the difference is underpayment value-added tax that must be paid by the Taxable Enterprises (Gordon, 2018; Harju et al., 2019; Olsen et al., 2019; Scheuer \& Werning, 2017).

Before Calculating Value-Added Tax (PPN), we have to know Tax Basis (DPP) that is used by a company. In article 1 section 17 UU PPN explained that, "DPP is number of selling prices, replacement, import value, or other value that is used as a basis for calculating the tax owed."

In article 1 section $18 \mathrm{UU}$ PPN the meaning of selling price is monetary value, including all costs requested or should be requested by the seller due to the delivery of BKP (Taxable Goods), not include PPN (Value-Added Tax) lawfully collected and discounted price listed in Tax Invoice. While in article 1 section 19 UU PPN the word of Replacement is used to deliver JKP (Taxable Services), Export Taxable Services, or Intangible Taxable Goods Export. In article 1 section 20 UU PPN, Import Value is monetary value that becomes the basis for calculating import duties plus levies based on the provisions in the legislation which regulates customs and taxes for the import of taxable goods, not include Value-Added Tax and Luxury Sales Tax (PPN and PPnBM) collected in accordance with the law of PPN. Another case with the Export Value, in Article 1 section 26 UU PPN, Export Value is monetary value, including all costs requested by exporter. Another Value is monetary value used as DPP set by Minister of Finance.

Considering the component to determine the owed value of PPN is so complex such as Tax Basis (DPP), time and place of tax owed, when the Taxable Enterprises (PKP) should make Tax Invoice for every transaction made, and if a company use mechanism of Output Tax and Input Tax, so they have to be able to differ between them based on the buying and selling activities carried out by the company and when they should credit, deposit the tax deficit and report the tax the tax authorities.

According to the statements above, so the writer is interested to do a research about the analysis of imposition, deposit, and reporting of Value-Added Tax by PT. Seimitsu Diagnostics, which will be outlined in a practical work report writing with the title: "The Analysis of imposition, deposit and reporting of Value-Added Tax by PT. Seimitsu Diagnostics." 
PT. Seimitsu Diagnostics is a private company, established in 2011 as a part of Kyowa Mediced Co.Ltd Japan, located in Mayapada Tower, $11^{\text {th }}$ Floor, Jl. Jendral Sudirman, Kav. 28, RT.4/RW.2, Kuningan, Karet, Jakarta 12920. PT. Seimitsu Diagnostics provides quality clinical chemical reagent products. Besides doing cooperation with clinic, it is also importing the product to run the business, so PT. Seimitsu Diagnostics can be said PKP which every transaction is recorded at the local Pratama Tax Office.

\section{METHOD}

The research approach that is used is analysis descriptive as mentioned by (Creswell, 2013; Creswell \& Creswell, 2017; Creswell \& Poth, 2018). The research is done at PT. Seimitsu Diagnostics located in Jl. Jendral Sudirman Kav.28 Kuningan, Karet, Jakarta (Mayapada Tower, $11^{h}$ floor). This company is engaged in medical tools. This research is done for 4 (four) weeks started on June $3^{\text {rd }}$ until June $28^{\text {th }} 2019$.

The Data Collecting Technique use three things as: 1) library research, 2) field research and 3) interview. 1) Library Research; The writer collects secondary data like written sources in the form of references, books, magazines, lecture materials and legislation of taxation which is related to the problems mentioned and explained by the writer. The research is done by reading, and learning after that applying the knowledge of the writer in arranging the report. 2) Field Research; is Primary source that is collected in the field by observing directly about the object, along at PT. Seimitsu Diagnostics. 3) Interview is method of collecting data by doing dialogue and asking the employees at PT. Seimitsu Diagnostics which handle the technique and nontechnique problems in taxation.

Data processing technique that is used is analysis descriptive, a research which is done based on the collecting and analysing data taken along the research and resulting a conclusion. (Miles et al., 2014).

\section{RESULT AND DISCUSSION}

\section{Research Result}

PT. Seimitsu Diagnosics is a private company which is established in 2011 as a part of Kyowa Mediced Co.Ltd Japan. Selection and use of the name "Seimitsu" comes from Japanese which in Indonesia Dictionary means "Presisi". The word Presisi here means accuracy. PT. Seimitsu Diagnostics use the name of "Seimitsu" because of the accuracy of the company in making medical tools and it has been tested for the quality. PT. Seimitsu Diagnostics registered as PKP since May 30 2011 in KPP Setiabudi Satu, South Jakarta. For about 8 years, PT. Seimitsu Diagnostics always focuses on giving the best for the customers and always support the government program in increasing the people's health by upholding product quality and partner with world-class companies which have international reputation in medical tools product. 


\section{0| Jurnal Office: Jurnal Pemikiran Ilmiah dan Pendidikan Administrasi Perkantoran}

Vol. 6, No. 1, January-June 2020, Page 37-44

Based on the activity at PT. Seimitsu Diagnostics which is engaged in medical tools, all goods / services delivery transactions carried out by companies are subject to tax in accordance with the legislation number 8 year 1983 as last modified by law number 42 year 2009 about Value-Added Tax of taxable goods and Luxury Sales Tax.

PT. Seimitsu Diagnostics is a company that has been confirmed as PKP and registered di KPP Setiabudi Satu, South Jakarta. As a taxable enterprise, PT. Seimitsu Diagnostics has Tax ID Number 03.157.203.5-011.000. As has been stated in Article 3A section (1) UU PPN, that every entrepreneur must report his business to be confirmed as Taxable Enterprises (PKP).

According to Article 1 section 15 UU PPN stated that "Taxable Enterprise is an entrepreneur who does the delivery of taxable goods and/or the delivery of taxable services which is subject to the value-added tax." PT. Seimitsu Diagnostics as PKP has obligations as follows: 1) Collect value-added tax on the delivery of taxable goods, and make tax invoice as a proof of collecting value-added tax, 2) Count and calculate value-added tax. If the output tax is bigger than the input tax (PK > PM), so for the difference must be deposited in the state treasury. If the output tax is smaller than the input tax (PK < PM), then for the difference is as the overpayment and can be compensated to the next tax period or restitution at the end of the year, 3) Deposit value-added tax owed and 4) Report value-added tax owed by fulfilling SPT period of PPN and report it to the local KPP.

\section{Tax Basis (DPP)}

DPP PPN used by PT. Seimitsu Diagnostics is in accordance with Article 1 section 17 UU PPN. Tax basis is the amount of selling price, replacement, Import Value, Export Value, or Other Value as a basis to calculate tax owed". The meaning of selling price in this point number as Article 1 section 18 "Selling price is monetary value, including all costs required or should be required by the the seller because of the delivery of taxable goods, not include value-added tax which is collected based on this law and discounted price listed in tax invoice".

\section{PPN Deposit Procedure}

Deposit occurs because there is tax owed is bigger than tax that has been paid (PK-PM). Otherwise, the deficiency must be deposited to the state treasury. The deposit is done by using tax payment slip (SSP), the finance department of the tax prepare a notification letter of ValueAdded Tax period (SPT Masa PPN) within the attachment that will be reported.

\section{PPN Reporting Procedure}

As in Article 15A section (2) UU PPN, Value-Added Tax reporting is no later than the following month after the end of Tax Period. After the tax is deposited then the accounting department attaches the SSP to the PPN period tax return within the attachment of SPT required such as: 1) Master Form of PPN period tax return 1111 (Notification of PPN period), 2) Form of $1111 \mathrm{AB}$ (Recapitulation of Submission and acquisition or Form of 1111AB), 3) Form of 1111 A1 (Export list of tangible Taxable Goods, intangible Taxable Goods, and/ or Taxable Services), 4) Form of 1111 A2 (List of Output Tax on domestic delivery with tax invoice), 5) 
Form of 1111 B1 (Input Tax that can be credited on import taxable goods and utilization of intangible taxable goods/taxable services from outside the customs area), 6) Form of 1111 B2 (Input Tax that can be credited on import taxable goods and utilization of intangible taxable goods/taxable services from outside the customs area), dan 7) Form of 1111 B3 (List of Input Tax that cannot be credited or get facilities). After all attachments have been delivered then PPN period Tax Return is submitted to the Finance Manager to be signed and labeled company. Then submitted to the tax office that has been determined,which is in KPP Setiabudi Satu.

According to data obtained from PT. Seimitsu Diagnostics for the tax period of January until December 2018, the company has underpayment tax difference because the output tax is bigger than the input tax about Rp. 272.493.188. PT. Seimitsu Diagnostics is supposed to deposit for the underpayment tax difference to state treasury as the applicable law. However based on the data obtained from PT. Seimitsu Diagnostics, PT. Seimitsu Diagnostics has not deposited the underpayment tax difference that has been calculated in the recapitulation of the output tax and the input tax in 2018, while the Director General of Taxes conduct an examination of PT. Seimitsu Diagnostics and issued tax underpayment assessment, so PT. Seimitsu Diagnostics reports the underpaid tax immediately.

As has been arranged in the article 9 section (4f) UU PPN PPnBM year 2016, if based on the result of the inspection as referred to the section (4e), Director General of Tax issued tax underpayment assessment, the amount of tax deficit added with administrative sanctions in the form of interest as referred to the article 8 section (2) Law number 6 year 1983 about the General Provisions and procedures for taxation and amendments, and article 13 section (2) Law number 6 year 1983 about the General Provisions and Amendments.

As the contents of the article 8 section (2) Law Number 6 Year 1983 about the General Provisions and Procedures of Tax and Amendment, Which is In the case of taxpayer, the company correct himself the notification letter which resulted in greater tax debt, causing the sanction of interest for $2 \%$ a month for the amount of the underpaid tax, calculated start from the delivery of notification letter until the date of payment due to the correction of notification letter. And article 13 section (2) Law number 6 Year 1983 about the General Provisions and Procedures of Tax and Amendment, which is the amount of the underpaid tax in the tax assessment as referred to the section (1) letter a added by the administration sanction in the form of interest for $2 \%$ a month for at least twenty four months. Calculated when the tax becomes due or the tax period ends, part of tax year or tax year until the issuance of the tax assessment letter.

\section{Discussions}

From the result of the research which is done by the writer along the observation and through interview with the tax staff of PT. Seimitsu Diagnostics and also the discussion about data by the writer, it can be stated that the obstacle for PT. Seimitsu Diagnostics is where the Output Tax difference is always bigger than the Input Tax due to PT. Seimitsu Diagnostics is a Taxable Enterprise (PKP) in Medical tools where the tools and the materials used by PT. Seimitsu Diagnostics to produce the products that have a long period of use so that PT. Seimitsu Diagnostics will do selling transactions more often than buying which causes the Output Tax 


\section{Jurnal Office: Jurnal Pemikiran Ilmiah dan Pendidikan Administrasi Perkantoran Vol. 6, No. 1, January-June 2020, Page 37-44}

difference is bigger than the Input Tax so that PT. Seimitsu Diagnostics is always having underpayment tax in every Tax Period or Tax Year.

The next problem is PT. Seimitsu Diagnostics as Taxable Enterprise is considered to be negligence in reporting underpayment taxes in every Tax Period or Tax Year so that when the writer does the research, there is a considerable amount of underpaid tax that have not been deposited to the state treasury. It is suitable with any kind of problems that is explained by researchers stated that the company tax sometimes experience of the negligence in reporting the tax that is caused by their own dense activity or the unknown of the rules implemented. (Ariel, 2012; Jallai \& Gribnau, 2018; Marres \& Weber, 2012; McGee, 1998; Morgan \& Sun, 2017; Osho \& Ilori, 2020; Sayidah \& Assagaf, 2019).

As for the effort made by PT. Seimitsu Diagnostics to overcome the problem faced by the company is doing coordination particularly in a reciprocal way with all related elements in doing transaction of selling/buying as well as Tax Staff to be more accurately and carefully in calculating the tax invoice and recapitulate Input Tax and Output Tax so that the company knows the amount of underpayment tax that should be deposited to the state treasury. PT. Seimitsu Diagnostics as an Taxable Enterprise who obeys the rules, it should be continually doing an audit or do correction of calculating tax invoice until recapitulation of the Input Tax and the Output Tax so that when the company face the same situation about underpayment tax, then taxation staff immediately deposited to the state treasury to avoid sanction of interest that will rise causing the worst situation for the company. (Soekirman et al., 2018). Besides that, PT. Seimitsu Diagnostics must be firmly against the staff who is responsible to prevent the delay in depositing and reporting tax to avoid the sanction by the company of the mistake or the delay of imposition of deposits and reporting of Value-Added Tax.

\section{CONCLUSION}

Basically, it has been in line with the Law number 42 Year 2009 about Value-Added Tax of Goods and Services and Luxury Sales Tax, in doing the imposition, deposit, and reporting of Value-Added Tax. In terms of invoicing, PT. Seimitsu Diagnostics in 2018 has used e-SPT as in Article 1 section (5) PER-03/PJ/2015. Depositing of Value-Added Tax by PT. Seimitsu Diagnostics has also been in line with the article 15A UU PPN. However, according to the writer there is still a fairly high tax rate that has not been deposited as the provisions (due date on $10^{\text {th }}$ of the following month, the tax should be deposited.

PT. Seimitsu Diagnostics is having the problem in the taxation system because PT. Seimitsu Diagnostics engaged in medical tools, where the tools and materials used to produce the product that have a long period in used, however PT. Seimitsu Diagnostics always does the large sales transactions because the needs of consumers on the medical 
tools keeps increasing and causing the Output Tax of PT. Seimitsu Diagnostics is bigger than the Input Tax.

PT. Seimitsu Diagnostics commits negligence in the taxation by not depositing and reporting the underpayment tax owed so that PT. Seimitsu Diagnostics should pay the underpayment tax within the interest which has been determined by the applicable law. Because of the negligence so the interest that should be paid is high enough because of the delay of deposit and sanction of the reporting delay of the underpayment tax.

\section{REFERENCES}

Aminu, A. (2019). A recursive dynamic computable general equilibrium analysis of valueadded tax policy options for Nigeria. Journal of Economic Structures, 8(1), 22.

Ariel, B. (2012). Deterrence and moral persuasion effects on corporate tax compliance: findings from a randomized controlled trial. Criminology, 50(1), 27-69.

Benzarti, Y., Carloni, D., Harju, J., \& Kosonen, T. (2017). What goes up may not come down: asymmetric incidence of value-added taxes. National Bureau of Economic Research.

Creswell, J. W. (2013). Research Design: Qualitative Approach, Quantitative and Mixed. Yogyakarta: Student Library.

Creswell, J. W., \& Creswell, J. D. (2017). Research design: Qualitative, quantitative, and mixed methods approaches. Sage publications.

Creswell, J. W., \& Poth, C. N. (2018). Qualitative inquiry Research Design Choosing Among Five Approaches (Vol. 53, Issue 9). SAGE Publications Ltd. https://doi.org/10.1017/CBO9781107415324.004

Gordon, R. (2018). How should taxes be designed to encourage entrepreneurship? Journal of Public Economics, 166, 1-11.

Hanifah, H., \& Yudianto, I. (2019). The Influence of Religiosity, Nationalism, and Tax Corruption Perception on Tax Compliance. Journal of Accounting Auditing and Business, 2(1), 24-34.

Harjanti, R. S., Karunia, A., \& Kamal, B. (2019). Analisis Tax Planning Dalam Rangka Mancapai Efisiensi Pajak Pertambahan Nilai (PPN) Pada PT Ramadhan Caturkarsa Layorda Tegal. Monex: Journal Research Accounting Politeknik Tegal, 8(2).

Harju, J., Matikka, T., \& Rauhanen, T. (2019). Compliance costs vs. tax incentives: Why do entrepreneurs respond to size-based regulations? Journal of Public Economics, 173, 139164.

Jallai, A.-G., \& Gribnau, H. (2018). Aggressive tax planning and corporate social irresponsibility: Managerial discretion in the light of corporate governance. Tilburg Law School Research Paper, 5.

Marres, O., \& Weber, D. M. (2012). Tax treatment of interest for corporations. IBFD. 
44| Jurnal Office: Jurnal Pemikiran Ilmiah dan Pendidikan Administrasi Perkantoran Vol. 6, No. 1, January-June 2020, Page 37-44

McGee, R. W. (1998). Ethical Views on Tax Evasion among Swedish CEOs: A Comment. Journal of Accounting, Ethics \& Public Policy, 1(3), 460-467.

Miles, M. B., Huberman, A. M., \& Saldana, J. (2014). Qualitative Data Analysis: A Methods Sourcebook (3rd ed.). Sage Publications.

Morgan, J., \& Sun, W. (2017). Corporations, Taxation and Responsibility: Practical and OntoAnalytical Issues for Morphogensis and Eudaimonia-A posse ad esse? In Morphogenesis and human flourishing (pp. 185-210). Springer.

Okello, A. (2014). Managing income tax compliance through self-assessment (Issues 14-41). International Monetary Fund.

Olsen, J., Kasper, M., Kogler, C., Muehlbacher, S., \& Kirchler, E. (2019). Mental accounting of income tax and value added tax among self-employed business owners. Journal of Economic Psychology, 70, 125-139.

Osho, A. E., \& Ilori, F. O. (2020). Influence of Transaction Transfer Pricing Policies on Corporate Organizations Tax in Nigeria.

Park, C. K. (2019). Tax policies and institutional reform. Korea's Political Economy: An Institutional Perspective.

Sayidah, N., \& Assagaf, A. (2019). Tax amnesty from the perspective of tax official. Cogent Business \& Management, 6(1), 1659909.

Scheuer, F., \& Werning, I. (2017). The taxation of superstars. The Quarterly Journal of Economics, 132(1), 211-270.

Soekirman, A., Rachmany, H., \& Happy, V. V. (2018). Analisis Implementasi Kebijakan Sistem Electronic Filing Sebagai Upaya Meningkatkan Kepatuhan Wajib Pajak dalam Penyampaian Surat Pemberitahuan Tahunan Kepada KPP PKEPADA KPP Pratama Tangerang Barat, Tahun 2013, 2014 dan 2015. Jurnal Reformasi Administrasi: Jurnal Ilmiah Untuk Mewujudkan Masyarakat Madani, 5(2), 174-184.

Wadesango, N., Mutema, A., Mhaka, C., \& Wadesango, V. O. (2018). Tax Compliance of Small and Medium Enterprises Through The Self-Assessment System: Issues and Challenges. Academy of Accounting and Financial Studies Journal. 